\title{
HUBUNGAN IBU HAMIL PEROKOK PASIF DENGAN KEJADIAN BAYI BERAT LAHIR RENDAH DI RUMAH BERSALIN IBU SRI PANUNTUN KLATEN
}

\author{
Sri Aminingsih ${ }^{1}$, Nadiya Istiqomah ${ }^{2}$
}

\begin{abstract}
Background: Smoking affects blood circulation and makes mothers and babies exposed to hazardous chemicals. Every time a mother smokes, her baby gets less oxygen. Nicotine in cigarettes decreases blood flow to the placenta. At the same time carbon monoxide (CO) lowers the amount of oxygen carried by blood. In addition, there are toxic chemicals that usually interfere the development of infants (Rahmalia, 2009). A preliminary study conducted by the author at the Maternity House of Sri Panuntun, Pedan Klaten District, there were 30 babies born in August to September 2017, revealed that there were 6 babies suffered from low birth weight, while 24 babies have normal birth weight.

The purpose: Describing the relationship of pregnant women passive smokers with the incidence of Low Birth Weight was the aim of this study.

The subjects : The population in this study was all mothers who gave birth at Maternity Mother Sri Panuntun Klaten in January-March 2018 accounted for 55 respondents.

The results: The result of this research by using Pearson Chi-Square correlation test obtained $p=0.000$.

The conclusion: There was a positive correlation between pregnant women who are passive smokers with the incidence of low birth weight babies.
\end{abstract}

Keywords: Pregnant women, Passive smokers, Low birth weight babies.

\section{PENDAHULUAN}

Merokok mempengaruhi peredaran darah dan membuat ibu maupun bayi terpajan bahan kimia berbahaya. Setiap kali ibu merokok, bayinya mendapatkan lebih sedikit oksigen. Nikotin dalam rokok menurunkan aliran darah ke plasenta. Pada saat yang sama karbon monoksida (CO) menurunkan jumlah oksigen yang biasa dibawa oleh darah. Selain itu terdapat bahan kimia toksik yang bisa mengganggu perkembangan bayi (Rahmalia, 2009).

Bayi yang lahir dari ibu yang merokok selama kehamilan berukuran lebih kecil dibandingkan bayi yang lahir dari ibu yang tidak merokok. Lebih besar pula kemungkinan bayi lahir terlalu dini dan mengalami masalah kesehatan langsung. Selama masa bayi, bayi lebih mudah jatuh sakit, lebih sering dirawat dirumah sakit, dan memiliki kemungkinan lebih besar untuk meninggal akibat sindrom kematian bayi mendadak atau Sudden Infant Death Syndrome (SIDS) (Rahmalia, 2009).

Bayi Berat Badan Lahir Rendah (BBLR) atau Low Birth Weight adalah yang bobotnya kurang dari 2500 gram. BBLR disebabkan oleh kelahiran yang tidak cukup bulan (prematur), cukup bulan tetapi kecil (proposional) dan IUGR (IntraUterine Growth Retardation) (Hayati, 2009).

Berat badan bayi lahir rendah dapat disebabkan karena umur kehamilan belum waktunya untuk lahir dan masih terjadi tumbuh kembang intrauteri. Bayi dengan berat badan lahir rendah dapat menjadi masalah karena bayi dengan BBLR mempunyai risiko mortalitas dan morbiditas yang tinggi, dampak psikologis dan neurologis setelah hidup dan akan menjadi masalah 
baru dalam lingkungan keluarganya, dan kelahiran dengan BBLR cukup sulit bahkan menggunakan alat canggih (Manuaba IBG, Manuaba IAC, dan Manuaba IBGF, 2011).

Penelitian yang dilakukan Ramadhan (2012), berdasarkan wawancara pada responden didapatkan 33 bayi (73.3\%) lahir dengan berat badan normal dan 12 bayi $(26.7 \%)$ lahir dengan BBLR (Bayi Berat Lahir Rendah). Dari 4 responden yang perokok pasif berat didapatkan 3 (75\%) ibu mengalami kejadian BBLR, dari 26 responden yang perokok pasif ringan di dapatkan 9 (34.6\%) ibu melahirkan bayi berat badan normal, sedangkan dari 15 responden yang tidak terpapar dengan asap rokok didapatkan $15 \quad(100 \%)$, ibu melahirkan dengan bayi berat badan normal (tidak mengalami kejadian BBLR). Maka dapat disimpulkan bahwa terdapat hubungan yang bermakna antara ibu hamil perokok pasif dengan kejadian BBLR.

Hasil penelitian yang dilakukan oleh Irnawati, Hamkini dan Wibowo (2011), menunjukkan 1-10 batang rokok yang dihisap perhari oleh perokok aktif di dalam rumah selama ibu hamil, berisiko bagi ibu hamil untuk melahirkan BBLR sebesar 2.47 kali. Paparan asap oleh perokok aktif yang merokok di dalam ruangan lebih dari 11 batang, berisiko 3.33 kali lebih besar bagi ibu hamil untuk melahirkan BBLR dibandingkan dengan ibu hamil yang tidak ada perokok di dalam rumahnya. Ibu hamil perokok pasif berisiko 1.8 kali untuk melahirkan BBLR. Kelahiran BBLR pada ibu hamil perokok pasif diakibatkan oleh paparan karbon monoksida (CO) yang terus menerus selama ibu hamil. Karbonmonoksida dapat diikat dalam $\mathrm{Hb}$ ibu sehingga mengakibatkan menurunnya kapasitas pengangkutan oksigen di dalam darah ibu, sehingga tubuh janin akan menerima oksigen lebih sedikit. Selain CO, nikotin juga dapat menyebabkan penurunan penerimaan oksigen janin. Akibatnya akan tumbuh dengan berat di bawah normal.

Studi pendahuluan yang penulis lakukan di Rumah Bersalin Ibu Sri Panuntun, Kecamatan Pedan Klaten, terdapat 30 bayi lahir dalam bulan Agustus sampai September 2017, diperoleh hasil 6 bayi mengalami berat badan lahir rendah, sedangkan 24 bayi memiliki berat badan lahir normal.

\section{TUJUAN PENELITIAN}

Tujuan umum untuk mengetahui hubungan ibu hamil perokok pasif dengan kejadian Bayi Berat Lahir Rendah. Tujuan khusus untuk mengidentifikasi perokok pasif, mengidentifikasi kejadian Bayi Berat Lahir Rendah dan menganalisa hubungan ibu hamil perokok pasif dengan Bayi Berat Lahir Rendah di RB Ibu Sri Panuntun Klaten.

\section{DESAIN PENELITIAN}

Pada penelitian ini penulis menggunakan desain penelitian korelasi dengan pendekatan metode cross sectional.

\section{POPULASI, SAMPEL, DAN TEKNIK SAMPLING}

Populasi pada penelitian ini adalah semua ibu yang melahirkan di Rumah Bersalin lbu Sri Panuntun Klaten pada bulan Januari-Maret 2018 berjumlah 55 responden. Teknik sampling yang digunakan dalam penelitian ini adalah dengan teknik sampling konsekutif. 
HASIL PENELITIAN

Tabel 1.

Distribusi Frekuensi Responden

Berdasarkan Umur, Pendidikan dan Riwayat Pekerjaan

\begin{tabular}{ccc}
\hline $\begin{array}{c}\text { Karakteristik } \\
\text { Responden }\end{array}$ & $\mathrm{f}$ & $\%$ \\
\hline Umur & & \\
$19-30$ & 40 & 72.70 \\
$31-42$ & 15 & 27.30 \\
Pendidikan & & \\
SD & 1 & 1.80 \\
SMP & 6 & 10.90 \\
SMA & 48 & 87.30 \\
Pekerjaan & & \\
Buruh & 24 & 43.60 \\
IRT & 14 & 25.50 \\
Swasta & 17 & 30.90 \\
\hline
\end{tabular}

Dari tabel di atas diperoleh informasi bahwa responden dengan kelompok umur terbanyak adalah 19-30 tahun berjumlah 40 responden $(72.70 \%)$, untuk riwayat pendidikan terbanyak adalah SMA berjumlah 48 responden (87.30\%). Sedangkan informasi tentang riwayat pekerjaan terbanyak adalah sebagai buruh berjumlah 24 responden (43.60\%).

Tabel 2.

Distribusi Frekuensi Perokok Pasif

\begin{tabular}{ccc}
$\begin{array}{c}\text { Perokok } \\
\text { Pasif }\end{array}$ & $f$ & $\%$ \\
\hline $\begin{array}{c}\text { Perokok } \\
\text { Tidak }\end{array}$ & 15 & 27.27 \\
\hline Jumlah & 55 & 72.73 \\
\hline
\end{tabular}

Dari tabel di atas dapat dicermati bahwa ibu hamil yang terpapar rokok berjumlah 15 responden $(27.27 \%)$, sedangkan yang tidak terpapar rokok (bukan perokok pasif) berjumlah 40 responden (72.73\%).
Tabel 3.

Distribusi Frekuensi Kejadian BBLR

\begin{tabular}{ccc}
\hline $\begin{array}{c}\text { Kejadian } \\
\text { BBLR }\end{array}$ & $f$ & $\%$ \\
\hline BBLR & 7 & 12.73 \\
BB Normal & 48 & 87.27 \\
\hline Jumlah & 55 & $100 \%$ \\
\hline
\end{tabular}

Dari tabel di atas dapat dicermati bahwa kejadian BBLR berjumlah 7 bayi yang dilahirkan (12.73\%) sedangkan bayi yang dilahirkan dengan berat badan normal berjumlah 48 bayi (87.27\%).

Tabel 4.

Tabulasi Silang

Hubungan Ibu Hamil Perokok Pasif dengan Kejadian BBLR

\begin{tabular}{cccc}
\hline \multirow{2}{*}{$\begin{array}{c}\text { Berat } \\
\text { Badan } \\
\text { Lahir }\end{array}$} & \multicolumn{2}{c}{ Perokok Pasif } & \\
\cline { 2 - 3 } & $\begin{array}{c}\text { Perokok } \\
\text { Pasif }\end{array}$ & $\begin{array}{c}\text { Tidak } \\
\text { Perokok } \\
\text { Pasif }\end{array}$ & Total \\
\hline BBLR & 7 & 0 & 7 \\
BB normal & 8 & 40 & 48 \\
\hline
\end{tabular}

Dari tabulasi silang didapatkan hasil bahwa ibu hamil yang terpapar rokok pasif adalah 15 responden melahirkan bayi dengan berat badan lahir rendah sebanyak 7 bayi, sedangkan 8 bayi diantaranya dilahirkan dengan berat badan normal. Sedangkan hasil uji Pearson Chi-Square program SPSS versi 18.0 dengan $\alpha=5 \%(0.05)$ diperoleh $p$ sebesar 0.000 sehingga nilai $p<0.05$, menunjukkan ada korelasi positif antara ibu hamil perokok pasif dengan kejadian Bayi Berat Lahir Rendah di Rumah Bersalin Ibu Sri Panuntun Klaten.

\section{PEMBAHASAN}

Berdasarkan hasil dari penelitian ini dapat dicermati bahwa ibu hamil perokok pasif berjumlah 15 responden $(27.27 \%)$, sedang ibu hamil yang tidak terpapar rokok berjumlah 40 responden (72.73\%). 
Ibu hamil yang terpapar rokok dalam penelitian ini adalah ibu hamil yang setiap hari selalu terpapar oleh rokok yang dihisap oleh pasangannya (suami). Perokok pasif adalah orang-orang yang tidak merokok tetapi terpaksa menghisap asap rokok. Perokok pasif akan menghisap asap sampingan (side stream smoke) yang keluar dari ujung batang rokok yang terbakar, selain itu juga menghisap bagian dari asap utama yang dihembuskan lagi oleh perokok aktif setelah menghisapnya. Penelitian menunjukkan bahwa rokok yang terbakar menghasilkan asap sampingan sejumlah dua kali lebih banyak dari asap utama, karena asap sampingan terus-menerus keluar selama rokok dinyalakan, sementara asap utama akan keluar kalau rokok itu dihisap (Jabbar, 2008). Sedangkan menurut Husaini (2010), perokok pasif atau yang terkadang dikenal dengan nama Involuntary Smoking adalah suatu istilah yang diberikan kepada mereka yang tidak merokok namun mereka seolah dipaksa untuk menghirup asap rokok yang ada disekelilingnya.

Menurut Prasetyono (2009), ibu hamil yang sering terkena asap rokok atau perokok pasif terancam melahirkan anak dengan masalah psikologi. lbu hamil yang merokok akan memiliki anak dengan tingkat kecerdasan rendah, tumbuh menjadi orang dewasa yang miskin, serta memiliki pasangan yang anti sosial.

Pendapat lain dari Jong (2010), bayi sebagai perokok pasif di dalam perut ibunya lewat ari-ari atau plasenta dan darah tali pusat. Tambahan lagi, bayi pada minggu pertama kehamilan saat pembentukan organ, sangat peka dan mudah terkena kelainan bawaan. Oleh karena itu dalam penelitian ini bisa dipakai sebagai gambaran bahwa dengan adanya paparan rokok selama ibu sedang mengalami kehamilan akan berpengaruh terhadap pertumbuhan dan perkembangan bayi khususnya terhadap berat badan bayi yang akan dilahirkan oleh seorang ibu. Adapun dampak dari perokok pasif menurut Jabbar (2008), adalah kanker paru-paru, yang dibuktikan dengan hasil penelitian di Jepang bahwa istri perokok mempunyai kemungkinan mengalami kanker paru-paru dengan perbandingan $20 \%$ - 50\% lebih tinggi daripada istri bukan perokok. Penelitian di Inggris menemukan bahwa mereka yang tidak merokok tetapi secara terus menerus terpapar asap rokok di lingkungan kerjanya mengalami gangguan pernafasan yang cukup berat. Belakangan ini para ahli menemukan hubungan antara penurunan berat bayi yang dilahirkan oleh istri seorang perokok akibat gangguan perkembangan janin selama dalam kandungan. Selain istri, anak-anak juga dapat menjadi perokok pasif. Penelitian menunjukkan bahwa keluhan pernafasan, batuk pilek dan sebagainya, ternyata $20 \%$ sampai $80 \%$ lebih sering terjadi pada anak perokok daripada anak bukan perokok. Kemungkinan untuk mendapatkan bronchitis dan infeksi paru-paru lain pada anak yang orang tuanya merokok, juga dua kali lebih sering bila dibandingkan dengan yang orang tuanya bukan perokok. Kebiasaan merokok pada orang tua meningkatkan kemungkinan terjadinya infeksi telinga pada anak. Anak-anak yang orang tuanya perokok tercatat lebih sering dirawat di rumah sakit karena gangguan pernafasan bila dibandingkan dengan mereka yang orang tuanya tidak merokok.

Dalam penelitian ini dapat dicermati bahwa persentase kejadian BBLR yang dilahirkan oleh ibu perokok pasif berjumlah 7 bayi (12.73\%), sedangkan bayi yang dilahirkan 
dengan berat badan normal berjumlah 48 bayi (87.27\%).

Menurut Dutton, Densmore, dan Turner (2012), dampak perokok pasif pada kehamilan meliputi BBLR (Bayi Berat Lahir Rendah), abrupsio plasenta, plasenta previa dan kelahiran prematur. Adapun pengertian BBLR menurut Masrurroh (2016), adalah bayi baru lahir dengan berat badan lahir kurang dari 2500 gram. Berat lahir adalah berat bayi yang ditimbang dalam satu jam setelah lahir. Istilah yang digunakan untuk mendefinisikan bayi yang lahir terlalu kecil, dan kelahiran preterm, atau prematur adalah istilah yang digunakan untuk mendefinisikan bayi yang lahir terlalu dini. Kelahiran preterm adalah salah satu dari situasi utama yang mengancam kesehatan manusia, menjadi penyebab terbesar dari morbiditas dan merekomendasikan definisi kelahiran preterm sebagai kelahiran yang terjadi selama 37 minggu gestasi.

Penyebab lain dari terjadinya BBLR menurut Masruroh (2016), adalah kelahiran prematur dan bayi kecil untuk masa kehamilan dan beberapa faktor predisposisi, salah satu diantaranya adalah berkaitan dengan umur ibu saat mengalami kehamilan. Dari data yang diperoleh dalam penelitian ini usia ibu saat hamil terbanyak adalah 19 tahun sampai 30 tahun. Sedangkan untuk faktor yang lain seperti faktor janin dan faktor plasenta belum diteliti.

Dari hasil penelitian hubungan ibu hamil perokok pasif dengan kejadian bayi berat lahir rendah diperoleh hasil Pearson Chi-Square program SPSS versi 18.0 dengan $\alpha=5 \%$ (0.05) diperoleh $p$ sebesar 0.000 sehingga nilai $p<0.05$, dengan hasil korelasi sangat tinggi 0.624 sehingga ada korelasi positif antara ibu hamil perokok pasif dengan kejadian bayi berat lahir rendah di rumah bersalin Ibu Sri Panuntun di wilayah Klaten.

Menurut Hayati (2009), berat badan lahir rendah atau Low Birth Weight adalah yang bobotnya kurang dari 2500 gram. BBLR disebabkan oleh kelahiran tidak cukup bulan (prematur), cukup bulan tetapi kecil (proposional), dan IUGR (IntraUterine Growth Retardation). Sedangkan menurut Arief dan Kristiyanasari (2009), BBLR dapat disebabkan oleh beberapa faktor, diantaranya adalah ibu yang merokok (baik ibu perokok pasif maupun ibu perokok aktif).

Dalam penelitian ini faktor yang mempengaruhi terjadinya BBLR adalah faktor ibu hamil yang terpapar asap rokok berjumlah 15 orang sedangkan bayi yang dilahirkan dengan berat badan lahir rendah sebanyak 7 anak sedangkan 8 anak dilahirkan dengan berat badan normal. Bayi dengan BBLR kemungkinan besar saat berada di dalam kehamilan ibu hamil tersebut terpapar oleh rokok yang setiap hari dihisap oleh pasangan ibu hamil (suami) didukung dari hasil wawancara diperoleh data bahwa 7 orang tersebut setiap hari terpapar oleh rokok, sedangkan 8 bayi yang dilahirkan dengan berat badan normal berdasarkan hasil kajian wawancara ibu saat menjalani kehamilan, pasangannya (suami) sangat jarang merokok. Responden yang lain yaitu 40 orang selama menjalani kehamilan memang sama sekali tidak terpapar oleh rokok sehingga bayi yang dilahirkanpun semua dalam kategori berat badan lahir normal. Merokok mempengaruhi peredaran darah dan membuat ibu maupun bayi terpajan bahan kimia berbahaya. Setiap kali ibu merokok, bayinya mendapatkan lebih sedikit oksigen. Nikotin dalam rokok menurunkan aliran darah ke plasenta. Pada saat yang sama Karbon Monoksida (CO) menurunkan jumlah oksigen yang 
biasa dibawa oleh darah. Selain itu terdapat bahan kimia toksik yang bisa mengganggu perkembangan bayi (Rahmalia, 2009).

Berdasarkan hasil penelitian yang dilakukan oleh Irnawati, Hakimi dan Wibowo (2011), menunjukkan rokok yang dihisap 1-10 batang perhari oleh perokok aktif di dalam rumah selama ibu hamil, berisiko bagi ibu hamil untuk melahirkan BBLR sebesar 2.47 kali. Paparan asap oleh perokok aktif yang merokok di dalam ruangan lebih dari 11 batang, berisiko 3.33 kali lebih besar bagi ibu hamil untuk melahirkan BBLR dibandingkan dengan ibu hamil yang tidak ada perokok di dalam rumahnya. Ibu hamil perokok pasif berisiko 1.8 kali untuk melahirkan BBLR. Kelahiran BBLR pada ibu hamil perokok pasif diakibatkan oleh paparan Karbon Monoksida (CO) yang terus menerus selama ibu hamil. Karbon Monoksida diikat dalam $\mathrm{Hb}$ ibu sehingga mengakibatkan menurunnya kapasitas pengangkutan oksigen di dalam darah ibu, sehingga tubuh janin akan menerima oksigen lebih sedikit. Selain CO, nikotin juga dapat menyebabkan penurunan penerimaan oksigen janin. Akibatnya akan tumbuh dengan berat di bawah normal.

Paparan di atas serupa dengan penelitian yang dilakukan oleh Hanum dan Wibowo (2016) mengenai pengaruh paparan asap rokok lingkungan pada ibu hamil terhadap kejadian berat bayi lahir rendah, hasil penelitian menunjukkan semakin lama ibu hamil bersama perokok aktif di dalam rumah dengan rata-rata ibu terpapar asap rokok $>7$ jam setiap harinya maka risiko melahirkan bayi dengan berat badan lahir rendah semakin tinggi. Ibu hamil yang perokok pasif yang terpapar asap rokok 1-10 batang/hari berisiko 2.4 kali lebih sering untuk terjadinya bayi berat lahir rendah. Asap rokok mengandung timbal yang jika terpapar pada ibu yang sedang hamil, maka akan mempengaruhi kesehatan ibu dan bayi. Hal ini dapat mempengaruhi berat lahir bayi dan menyebabkan keterlambatan perkembangan pada anak-anak. Sementara zat lain seperti CO dari rokok yang terisap oleh ibu hamil akan terbawa ke aliran darah ibu sehingga menyebabkan penerimaan oksigen bayi maupun plasenta berkurang, yang berarti berkurang juga penerimaan nutrisi untuk bayi. Hal ini akan mengakibatkan kematian sel karena kekurangan oksigen. Hipoksia pada janin dan menurunnya aliran darah umbilikal dapat menyebabkan gangguan pertumbuhan pada janin sehingga menyebabkan bayi berat lahir rendah.

\section{KESIMPULAN}

Hasil uji Pearson Chi-Square program SPSS versi 18.0 dengan $\alpha=5 \%(0.05)$ diperoleh $p$ sebesar 0.000 sehingga nilai $p<0.05$, sehingga ada korelasi positif antara ibu hamil perokok pasif dengan kejadian Bayi Berat Lahir Rendah di Rumah Bersalin lbu Sri Panuntun Klaten.

\section{SARAN}

1. Ibu hamil diharapkan menghindari paparan asap rokok selama menjalani kehamilan sehingga pertumbuhan dan perkembangan bayi tidak terhambat.

2. Puskesmas dapat memberikan promosi kesehatan tentang bahaya paparan asap rokok bagi ibu hamil.

3. Peneliti selanjutnya diharapkan untuk meneliti faktor- faktor lain yang mempengaruhi terjadinya bayi berat lahir rendah selain variabel perokok pasif. 


\section{DAFTAR PUSTAKA}

Arief Z.R. dan W. Kristiyanasari. 2009. Neonatus dan Asuhan Keperawatan Anak. Nuha Medika, Yogyakarta.

Dutton, L. A., J. E. Densmore dan M. E. Turner. 2012. A Pocket Guide To Clinical Midwifery : The Efficient Midwife. Alih bahasa Devi Yulianti. Buku Kedokteran EGC, Jakarta.

Hayati, A. W. 2009. Buku saku Gizi bayi.

https://books.google.co.id/book s?id. Diakses tanggal 15 September 2017.

Hanum, H. dan A. Wibowo. 2016. "Pengaruh Paparan Asap Rokok Lingkungan pada lbu Hamil terhadap Kejadian Berat Bayi Lahir Rendah". Mojority. 5. Lampung. Diakses pada tanggal 26 September 2017.

Husaini, A. 2010. Tobat Merokok. https://books.google.co.id/book s?id. Diakses pada tanggal 15 November 2017.

Irnawati, M. Hakimi dan T. Wibowo. 2011. "Ibu Hamil Perokok Pasif Sebagai Faktor Risiko Bayi Berat Lahir Rendah". Jurnal Gizi Klinik Indonesia. 8. Aceh. Diakses pada tanggal 26 September 2017.

Jabbar, A. 2008. "Nge-rokok Bikin Kamu Kaya". https://books. google. co. id/ books?id. Diakses pada tanggal 15 September 2017
Jong, W. D. 2010. Kanker Apakah Itu? Pengobatan, Harapan Hidup, Dan Dukungan Keluarga.

https://books.google.co.id/book $\mathrm{s}$ ?id. Diakses pada tanggal 13September 2017.

Manuaba, I. B. G., I. A. Chandranita Manuaba dan I. B. G. Fajar Manuaba. 2011. Pengantar Kuliah Obstetri. https://books.google.co.id/book s?id. Diakses pada tanggal 11 September 2017.

Masruroh. 2016. Buku Ajar Kegawatdaruratan Maternal \& Neonatal. Parama Publishing, Yogyakarta.

Prasetyono, D. S. 2009. Mengenal Menu Sehat Ibu Hamil. DIVA Press, Yogjakarta.

Rahmalia, A. 2009. Tanya Jawab Seputar Kehamilan. PT Bhuana IImu Populer, Jakarta.

Ramadhan, N. 2012. "Hubungan Ibu Hamil Perokok Pasif dengan Kejadian Bayi Berat Lahir Rendah Di Badan Layanan Umum daerah RSU Meuraxa Banda Aceh. Jurnal IImiah STIKES U'Budiyah. 1. Banda Aceh. Diakses pada tanggal 26 September 2017.

${ }^{1}$ Dosen Akper Panti Kosala

Surakarta

${ }^{2}$ Mahasiswa Akper Panti Kosala

Surakarta 
"KOSALA" JIK Vol. 6 No. 1 Mei 2018 